\title{
ANGKLUNG TRADISIONAL SUNDA: INTANGIBLE, CULTURAL HERITAGE OF HUMANITY, PENERAPANNYA DAN PENGKONTRIBUSIANNYA TERHADAP KELAHIRAN ANGKLUNG INDONESIA
}

\author{
Oleh: Asep Nugraha \\ Prodi Seni Karawitan ISBI Bandung \\ Jalan Buahbatu 212 Bandung \\ kangasepnugraha@gmail.com
}

\begin{abstract}
Angklung consists of two to four bamboo tubes suspended in a bamboo frame, bound with rattan cords. The tubes will produce certain notes when the frame is shaken or tapped. Each angklung produces a single note or chord, so several players must collaborate in order to play melodies. Traditional Angklungs use the pentatonic scale, but in 1938 musician Daeng Soetigna introduced Angklungs using the diatonic scale, known as angklung padaeng. Angklung is closely related to traditional customs, arts and cultural identity in Indonesia, played during ceremonies such as rice planting and harvest. Angklung education is passed down orally from generation to generation, and increasingly in educational institutions (Prodi Angklung and Musik Bambu ISBI Bandung. Angklung has been included in the UNESCO's (United Nations Educational, Scientific, Cultural Organization) list of intangible cultural heritage of humanity. This paper discusses the interesting things about the angklung. Especially the process of traditional angklung that developed into the modern angklung and then both has been worldwide as Indonesian culture heritage.
\end{abstract}

Keywords : angklung, Baduy, Indonesian, Padaeng.

\begin{abstract}
Abstrak
Angklung terdiri atas dua - empat tabung bambu dalam bingkai bambu, diikat dengan tali rotan. Tabung bambu akan menghasilkan nada tertentu ketika bingkai diguncangkan. Setiap angklung dapat menghasilkan nada tunggal atau akord, sehingga beberapa pemain berkolaborasi dalam memainkan melodi. Angklung tradisional menggunakan skala pentatonik, tetapi pada tahun 1938 seniman bernama Daeng Soetigna memperkenalkan angklung yang menggunakan skala diatonis, yang dikenal sebagai angklung padaeng. Angklung berkaitan erat dengan adat istiadat, seni dan identitas budaya di Indonesia, dimainkan pada upacara menanam padi dan panen. Transmisi skill memainkan angklung diturunkan secara lisan dari generasi ke generasi, dan semakin berkemabng setelah di masukan dalam lembaga pendidikan (Prodi Angklung dan Musik Bambu ISBI Bandung). Angklung dikukuhkan UNESCO (United Nations Educational, Scientific, Cultural Organization) sebagai daftar warisan budaya takbenda kemanusiaan. Makalah ini membahas hal-hal yang menarik tentang angklung. Terutama angklung tradisional yang berkembang menjadi angklung modern dan kemudian keduanya menjadi mendunia sebagai warisan budaya Indonesia.
\end{abstract}

Kata Kunci: angklung, Indonesia, masyarakat sunda, angklung tradisional 


\section{A. Pendahuluan}

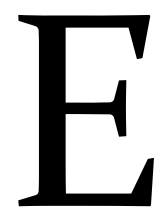

nsembel perkusi yang terbuat dari bambu, teridentifikasi sebagai alat musik yang umumnya digunakan pada peradaban kuna di wilayah Asia dan kepulauan di Samudera Pasifik ${ }^{1}$ (Rendall Baier, 1985:8). Praktik kuna bermain musik disajikan dengan suara manusia atau dengan alat musik yang terbuat dari bambu dan kayu yang pembuatannya tidak menerapkan teknologi tinggi (Mack, 2003:8). Tulisan ini membahas ensemble perkusi dari bambu yang berada di wilayah tersebut, yakni angklung ${ }^{2}$ pada masyarakat Sunda yang berada di

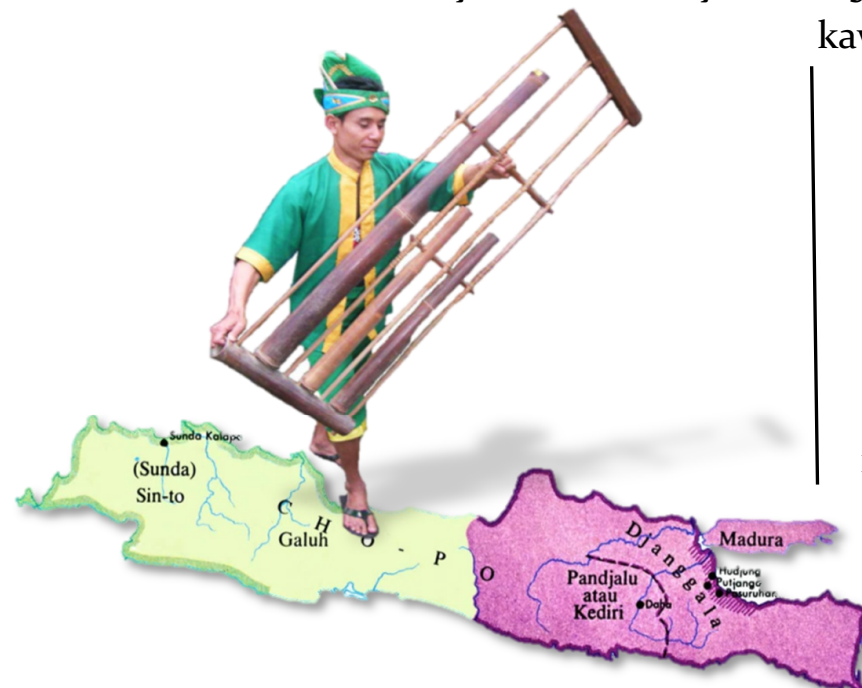

Peta kerajaan Sunda yang dipindai dari buku Atlas Sedjarah karya Muhammad Yamin (1956), poto pemain Angklung Buncis (Asep Nugraha) kawasan Samudra Pasifik, tepatnya di kepulaan Nusantara atau Indonesia.

Sekitar tahun 1985 pertunjukan angklung tradisional menjamur di kota, kabupaten, dan pedesaan (Rendall Baier, 1985:8). Entitasnya sempat terasing pada lokusnya sendiri, termarginalkan dan dipelihara minoritas masyarakat Sunda yang terkotakkotak, yakni masyarakat adat yang mempertahankan cara ciri tatali keruhun, antara lain komunitas adat Cipta Gelar di Sukabumi, masyarakat adat Cigugur di Kabupaten Kuningan, komunitas adat Cireundeu di Cimahi Selatan, dan masyarakat Kanekes di Banten Selatan.

Angklung tradisional merupakan instrumen yang menyertai tradisi pertanian masyarakat Sunda, dimainkan sebagai persembahan bersifat transenden kepada Nyi Pohaci Sanghyang Sri atau Dewi Padi. Kondisi tersebut menjadi berbeda, ketika Islam menjadi agama mayoritas masyarakat Sunda dengan pelaksanaan secara kaffah, menyebabkan ritual kepercayaan kepada tokoh mitologi Sunda dari 'dunia atas' kahiyangan -, percaya pada kekuatan transendental dewa-dewi membantu manusia mengolah pertanian dan angklung sebagai mediumnya direinterpretasi sebagai sesuatu yang absurd. Semenjak itu angklung tradisional dan prosesi upacara ritual penghormatan Dewi Padi kurang mendapat porsi untuk tampil di ruang publik luas.

${ }^{1}$ Samudra Pasifik berisi sekitar 25.000 kepulauan (lebih dari jumlah kepulauan yang berada di lautan dunia lainnya jika digabung), yang mayoritas terletak di selatan khatulistiwa. Di batasan ireguler Samudra Pasifik terdapat banyak lautan, yang terbesar adalah Laut Sulawesi, Laut Koral, Laut China Timur, Laut Jepang, Laut China Selatan, Laut Sulu, Laut Tasman dan Laut Kuning. Selat Malaka menghubungkan Samudra Pasifik dengan Samudra Hindia di sebelah barat, dan Selat Magelhaens menghubungkan Samudra Pasifik dengan Samudra Atlantik di sebelah timur

2 Angklung di Jawa Barat, dikenal sebagai alat musik yang terbuat dari bambu, dibunyikan dengan cara digoyangkan atau digetarkan. Penyebutan Angklung di Bali ditujukan untuk menyebut seperangkat gamelan yang biasa disebut gamelan angklung. 
Perubahan sosial dan gencarnya pembangunan, pada segala bidang kehidupan, menyebabkan orang Sunda memilih proesi menjadi buruh pabrik atau pegawai kantoran dan melakukan urbanisasi bekerja di pusat pemerintahan (kota), meninggalkan lahan pertanian di 'kampung halaman' yang semakin sempit karena dijual kepada pengusaha untuk didirikan pabrik. Profesi sebagai tuan tanah atau petani bukan lagi orientasi pekerjaan yang diproyeksikan di 'masa depan', tetapi orientasi tertuju pada sektor pekerjaan lain yang lebih menjanjikan dan bernilai prestise. Perubahan paradigma pada satu aspek kehidupan menyebabkan perubahan pada aspek lain. Bergesernya pandangan keagamaan dan aktivitas sosial budaya lambat laun menggeser kepercayaan kepada Dewi Padi: Padi tidak lagi disimpan di leuit ${ }^{3}$ dengan prosesi tetabuhan seperti pada jaman dahulu; angklung tidak lagi dimainkan di sawah dan ladang untuk mengibur Dewi Padi atau agar hama tanaman 'kabur' dan tanaman padi tumbuh subur; sekarang orang Sunda jarang memiliki leuit atau goah4 sebagai tempat penyimpanan hasil bumi dengan berbagai sesaji. Pendek kata, perubahan struktur fungsional masyarakat Sunda yang tidak menempatkan pertanian sebagai mata pencaharian yang utama, dan perkembangan ilmu pengetahuan serta teknologi, menyebabkan orang Sunda yang masih bertahan bertani, juga lambat laun meninggalkan tradisi pertanian bersifat mistis, termasuk keseniannya, yakni angklung tradisional. Mereka lebih menekankan berpikir realistis dan ekonomis dalam menjalankan profesi menggarap lahan pertanian.

Perubahan orientasi sumber mata pencaharian menyebabkan jumlah orang Sunda yang berprofesi sebagai petani berkurang, kesatuan anggota masyarakat adat melemah, imbasnya pasokan beras pérélék di lumbung desa menjadi berkurang. Padahal hasil bumi atau beras pérélék yang disisihkan masyarakat untuk disimpan di lumbung desa atau leuit tetua adat, berkontribusi membiayai dan menjaga keberlangsungan tradisi pertanian beserta ritus yang menyertainya. Beras pérélék digunakan masyarakat desa ketika tertimpa paceklik dan bencana kekeringan. Tidak heran, karena kaitan dengan kepentingan komunal, penyimpanan beras pérélék di lumbung desa atau di tetua masyarakat adat disertai prosesi ritual kesenian angklung dan rengkong sebagai bagian ritus yang berkaitan rasa syukur atas hasil panen, khususnya kepada Dewi Padi atau Nyai Pohaci Sanghyang Sri. Fenomena ini seperti ditulis Beir pada tahun 1985:

It is often the case that local farmers will give a share of their harvest to communal rice barn, and processions of bearers, led from the fields by an angklung ensemble and several rengkong players, will weave their way through the village to take the rice to its new home. Rengkong, a curious relative of

\footnotetext{
${ }^{3}$ Leuit adalah nama bangunan tempat penyimpanan padi secara tradisional (Rosidi, 2000:380)

${ }^{4}$ Goah adalah ruangan rumah yang letaknya di bagian belakang, meliputi ruangan tempat menyimpan makanan (Rosidi, 2000:247).
} 
angklung, is a specially shaped bamboo carrying pole that creates a loud, echolike sound when the rice bundles it carries rub against its sides.

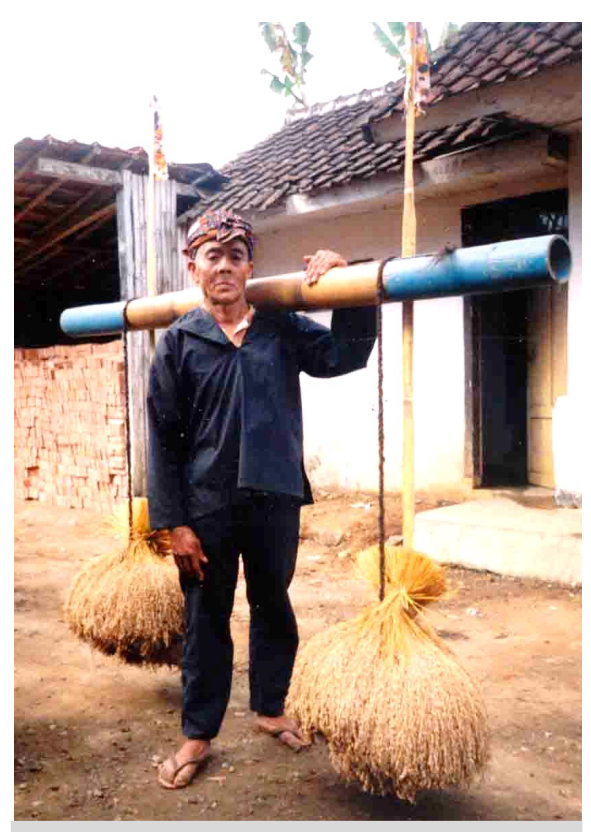

Rengkong, berperan multifungsi sebagai alat musik bambu dan alat mangangkut padi (Dok. Asep Nugraha)

Banyak kekayaan pengetahuan angklung tradisional yang belum terungkap, terklasifikasi, dan terkategorisasi, masih tersimpan dalam benak individu dan kelompok masyarakat adat yang masih setia mendukungnya. Diperlukan usaha untuk segera mengumpulkan kekayaan pengetahuan tersebut. Hal itu semakin krusial setelah angklung diakui organisasi pendidikan, ilmu pengtahuan, dan kebudayaan (UNESCO) Perserikatan Bangsa-Bangsa (PBB) sebagai Warisan Budaya Tak Benda Indonesia atau Intangible, Cultural Heritage of Humanity (Fikri, Tempo, 18 Oktober 2010). Pengakuan tersebut menyisakan beban tanggung jawab yang besar, karena dalam jangka waktu empat tahun, apabila Indonesia tidak melestarikan dan mengembangkan angklung, maka pengakuan dari UNESCO bisa dicabut (Pradoko, 2013:33)

Oleh karena itu, pengetahuan kekayaan Angklung yang masih berserakan harus segera diklasifikasi, dikategorisasi, dikonseptualisasi, diformulasikan, dan ditulis berdasarkan prinsip kerja ilmiah. Pemerintah Republik Indonesia melalui Kementerian Pendidikan dan Kebudayaan membuka Program Studi (Prodi) Angklung dan Musik Bambu pada Sekolah Tinggi Indonesia (STSI) di Bandung (sekarang: Institut Seni Budaya Indonesia (ISBI) Bandung), yang secara resmi aktif tanggal 27 April 2012, bentuk nyata pengejawantahan mandat untuk menjaga dan melestarikan keberadaan Angklung sebagai Warisan Tak Benda bangsa Indonesia dan juga pencitraan (baca: identisas) Indonesia di mata dunia internasional. Angklung tidak lagi berbicara pada tataran estetik musikal semata. Secara nyata memasuki ranah ilmu pengetahuan, seiring dengan hasil pengkajian para dosen Prodi Angklung dan Musik Bambu ISBI Bandung yang melakukan penelitian ilmiah serta praktik di laboratorium untuk pelestarian dan pengembangan entitas musik angklung.

\section{B. Metode}

Menulis angklung tidak lepas dari interval waktu antara angklung pada jaman dahulu dan sekarang. Oleh karena itu, metodelogi sejarah menjadi penting untuk diketengahkan, di mana angklung sebagai hasil tindakan manusia dalam sejarah harus dapat dipelajari dan dituliskan, baik dari sudut pelaku maupun penulis. Menginterpretasi sudut pandang pelaku pada masa lampau ditulis dengan melakukan penelusuran sumber sejarah, yakni sejumlah pustaka atau literatur yang berkaitan 
dengan fenomena angklung pada masa lampau dan sekarang. Sedangkan sudut pandang penulis adalah interpretasi dari fenomena peristiwa angklung dengan mengemukakan pandangan-pandangan. Oleh karena itu, tulisan ini menitikberatkan pendekatan analisis situasional. Dalam artian, angklung melalui tindakan konkrit yang telah ditorehkan masyarakat pendukungnya dikaji dalam hubungannya dengan situasi. Hal ini memberikan informasi mengenai angklung yang komprehensif dan bermakna.

\section{Pembahasan}

Dekade angklung tradisional yang sempat mengenyam kevakuman, langka dipresentasikan pada ritual pertanian, merupakan konsekwensi logis dari perubahan orientasi masyarakat pendukung utamanya. Posisinya menjadi tidak strategis secara ruang dan waktu. Secara ruang terdesak oleh jenis musik yang disuport industri kapitalis melalui media televisi yang intens menayangkan jenis musik yang dipandang bernilai marketable, seperti: pop, dangdut, hiphop, rock, jazz, dan sebagainya. Secara waktu, suka atau tidak suka, mau atau pun tidak mau, angklung berhadapan dengan jaman yang disebut globalisasi, di mana perkembangan mode, musik, dan budaya dari belahan dunia lain dengan mudah dikonsumsi dan menjadi trendsetter masyarakat Indonesia dengan hanya menekan 'satu tombol' saja. Akhirnya angklung tradisional menghadapi kendala dilematis: di satu sisi mesti survive saat berkompetisi dengan musik populer, sedangkan di sisi lain berhadapan dengan bangsa sendiri yang terpengaruh oleh trend atau orientasi cara menikmati musik yang berbeda.

Seolah-olah mendapat 'tenaga tambahan' untuk bangkit dari keterpurukan, angklung terlepas dari posisi staganasi. Negara tetangga Malaysia yang mengajukan klaim atas kepemilikan angklung dan kesenian Indonesia - batik, tari pendet, kuda kepang, dan reog ponogoro, membuat bangsa Indonesia: tua, muda, dewasa, dan anakanak terjaga dari 'mimpi semunya.' Mimpi mengenai ketergantungan mereka terhadap budaya, mode, fashion, dan musik bangsa lain. Klaim Malaysia atas angklung membangun kesadaran etnisitas (ethnicity) atau kebangsaan, bahwa Indonesia memiliki identitas yang berbeda dengan bangsa lain. Etnisitas tersebut menyebabkan bangsa Indonesia kembali peduli untuk memikirkan kesenian sendiri, menjaganya agar tidak dirampas kepemilikannya oleh bangsa lain. Peristiwa tersebut menjadi momentum untuk menata kekayaan seni tradisi yang dimiliki bangsa Indonesia, khususnya musik bambu angklung.

Secara objektif kekayaan angklung belum diketahui secara pasti, antara lain instrumen yang digunakan, musikalitas, cara memainkan, organisasi musikal, fungsi angklung dalam konteks kehidupan sosial budaya, maknanya bagi masyarakat pendukung, sistem tangga nada, sisi historis, sistem transmisi, tokoh yang memiliki kontribusi dan yang bertindak sebagai agent of change, serta pertanyaan lainnya. Hal ini menjadi 'pekerjaan rumah' yang harus dibenahi untuk dilengkapi melalui kegiatan 
penelitian atau pengkajian, diseminarkan, dan hasilnya dimuat pada sejumlah jurnal ilmiah nasional dan internasional, termasuk dalam jurnal Awi Laras Prodi Seni Angklung dan Musik Bambu ISBI Bandung.

\section{Penelusuran Istilah Angklung}

Beberapa peneliti menelisik ihwal penamaan Angklung sebagai cara memberi nama dengan pendekatan onomatopoea 5 , yakni mengidentifikasi kemiripan bunyi berdasarkan wacana lisan untuk disematkan menjadi identitas instrumen. Hal ini disinggung Baier yang menelusuri asal-usul penyebutan angklung, ternyata berasal dari suku kata -( $k l)$ ung sebagai ejaan lisan atas bunyi instrumen bersangkutan saat ditabuh. Ulasan Baier: It is difficult to trace the origins of the word 'angklung,' but some mucisians consider the -(kl)ung syllable to refer to the resonant quality of the bamboo sound (Baier, 1985:8). Dengan kata lain, bunyi instrumen berbahan dasar bambu ini, diinterpretasi orang Sunda dengan pelafalan 'lung' atau 'klung', dijadikan rujukan untuk memberi nama instrumen, 'Ang-klung'. ${ }^{6}$ Wacana lisan suku kata -ung sebagai akhiran untuk penamaan instrumen dari bahan bambu, secara nyata ditemukan pada instrumen musik bambu lain di Sunda, disenyalir usianya sama dengan angklung, antara lain calung, kunclung, dan celempung.

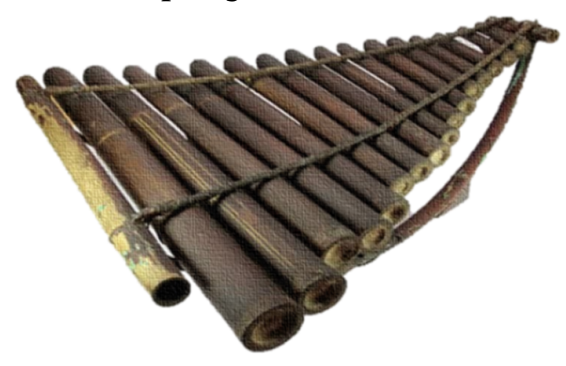

Alat musik Calung Rante

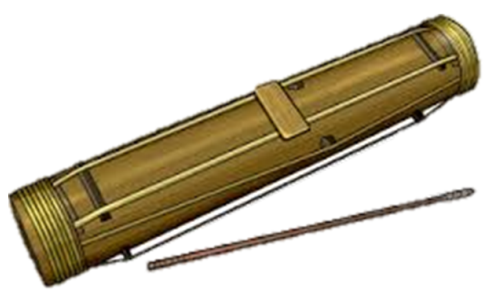

Alat musik Celempung

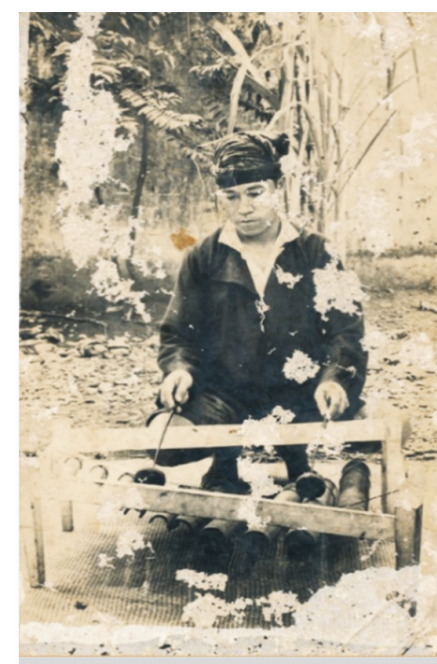

Kunclung Badui (Dok. Enoch Atmadibrata)

Pendekatan onomatopoea untuk penamaan angklung oleh komunitas masyarakat pendukung kesenian pada masa lampau diulas Spiller sebagai berikut:

Very often both bronze and bamboo musical instruments bear name that imitate the sound they make. The syllable "klung" in angklung, for example, captures the

${ }^{5}$ Onomatopoea dalam Kamus Bahasa Indonesia (2008) adalah kata atau nama yang terbentuk dari peniruan bunyi (Pusat Bahasa, 2008:1020).

${ }^{6}$ Hal itu seperti penamaan jentreng untuk kacapi di Sumedang yang diambil dari onomatope bunyi kacapi ketika dimainkan atau instrumen ngek ngek untuk penamaan alat musik tradisional yang dimainkan dengan cara digesek di desa Rancakalong Kabupaten Sumedang. Bentuk onomatope untuk penamaan peristilahan dalam Karawitan di Sunda menjadi hal yang biasa terjadi, seperti instrumen goong, kempul, kendang, dan sebagainya. 
resonant quality of the bamboo rattling against the instrument's frame as the player shakes it. Speakers of Sundanese, take the onomatopoeia (Spiller, 2008:12).

Angklung dideskripsikan sebagai instrumen yang terbuat dari bambu, dengan tabung bambu sebagai resonator, yang dibunyikan dengan cara digoyangkan (Suparli, 2009:14). Pendeskripsian tersebut serupa dengan Rosidi yang menulis angklung sebagai instrumen musik dari ruas bambu yang dimainkan dengan digoyangkan

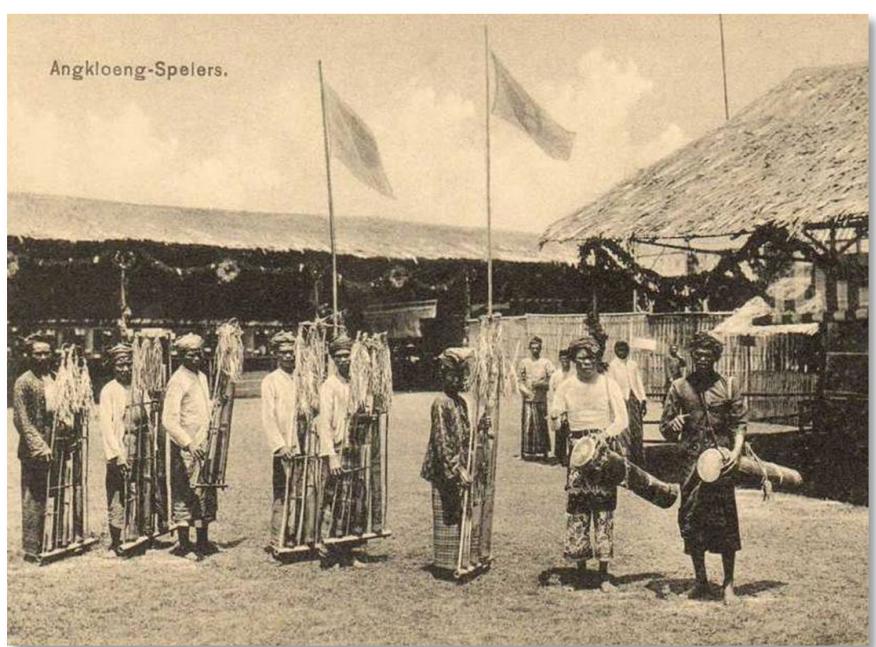

Angklung dalam bidikan kamera pemerintah Hindia Belanda (Dok. KILTV, Unversiteit Leiden)

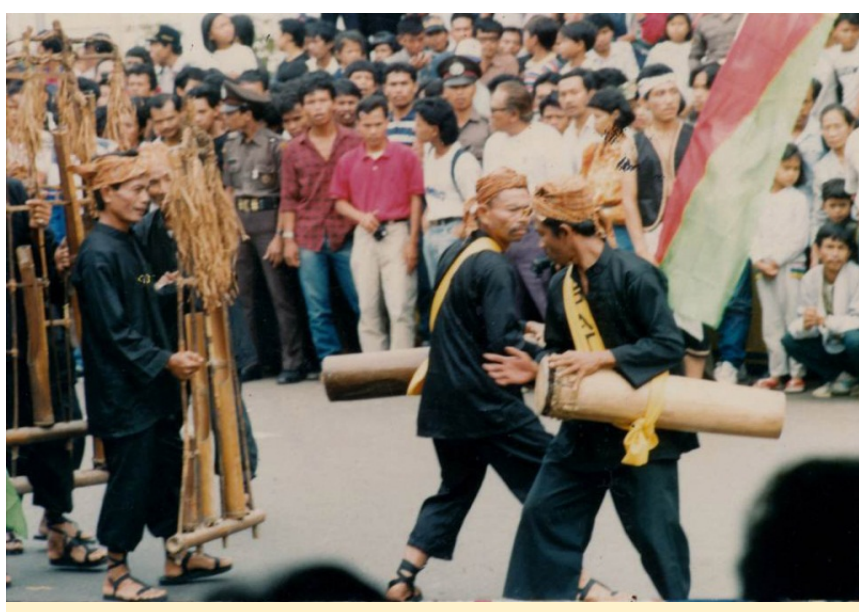

Jenis Angklung yang sama pada Dok. KILTV, Unversiteit Leiden yang didokumentasikan pada tahun 1983 (Dok. Enoch Atmadibrata)

tangan (Rosidi, 2000:51). Kedua pendeskripsian tidak eksplisit menyebutkan wilayah budaya yang menjadi locus instrumen angklung, tetapi implisit tersirat pada tajuk buku dengan menyertakan istilah Sunda.7 Pendeskripsian istilah angklung dalam Kamus Bahasa Indonesia (2008), terbitan Departemen Pendidikan Nasional (Depdiknas), menulis Sunda sebagai daerah asal mula kesenian angklung: "Angklung adalah alat musik tradisional daerah Sunda yang terbuat dari tabung bambu" (Pusat Bahasa, 2008:72). ${ }^{8}$

Penelusuran istilah angklung menjadi terbantahkan sebagai milik satu suku di Indonesia, karena penelitian Jaap Kunst pada tahun 1948, menuliskan keberadaan angklung yang hidup di wilayah cakupan yang besar, yakni Indonesia. Laporan Kunst ditulis dalam buku Music in Java, sebagai berikut:

In recent times, however, Angklung is still reported as having been seen in the territory of Banyumas, Cirebon, Brebes, Purbalingga, Wanasaba, Begelen, Yogya, Sola; in the regencies Panaraga, Trenggalek, Tulung Agung, Majakerta, Sidaarja, Grisee, Surabaya, and Purbalingga; as well as Madura, Bali,

\footnotetext{
7 Judul buku yang ditulis Suparli adalah Peristilahan Karawitan Sunda (2008). Sedangkan buku yang ditulis Rosidi adalah Ensiklopedi Sunda (2000)

${ }^{8}$ Istilah Angklung dalam Kamus Bahasa Indonesia menunjukan bahwa istilah tersebut telah diakui sebagai bahasa serapan dari bahasa daerah (baca Sunda) yang menjadi kosa kata bahasa Indonesia. Artinya secara nasional Angklung telah diakui sebagai puncak-puncak kebudayaan daerah yang mampu merepresentasikan kebudayaan Nasional, sama halnya dengan batik dan kebaya.
} 
South Sumatera and S.W. Borneo ... (Kunst, 1948:361).

Data pemerintah kolonial Belanda di Indonesia melalui penelitian Kunst mempertegas angklung sebagai produk budaya bangsa Indonesia, berkesesuaian dengan catatan British (Inggris) yang menduduki Malaysia 346 tahun, rentang waktu yang relatif sama dengan Belanda yang menduduki Indonesia. Encyclopaedia Britannica yang berkedudukan di Inggris dan dapat diakses secara online, memberi informasi mengenai keberadaan angklung yang tidak pernah ditemukan di Malaysia (selama British menjajah Malaysia dari tahun 1842-1957), tetapi hanya ditemukan di wilayah Indonesia. Penelusuran istilah angklung pada Encyclopaedia Britannica adalah: "A sliding rattle called angklung, found only in Indonesia, consists of several tuned bamboo tubes with cut-back tongues, inserted into a frame; they slide back and forth when the frame is shaken." (http://www.britannica.com).

Penelusuran istilah angklung dari beberapa literatur menghasilkan sintesa, bahwa angklung adalah warisan budaya dari Indonesia, terlepas di kemudian hari, entitas angklung Sunda lebih berkembang dan populer dari pada angklung lain di Indonesia, dan angklung Sunda pula yang dijadikan dasar keputusan PBB melalui UNESCO, mengakui angklung sebagai Warisan Tak Benda dunia atau Intangible, Cultural Heritage of Humanity. Angklung di Indonesia adalah artefak yang terpelihara dan terus-menerus dikembangkan hingga sekarang.

\section{Angklung dari Indonesia yang diakui Unesco}

Angklung diakui sebagai Warisan Budaya Dunia Tak Benda milik Indonesia. Pertanyaan yang muncul adalah angklung yang mana? jenis apa? dan ada pada kesenian apa? Pertanyaan bersifat fundamental mengingat Indonesia memiliki varian angklung seperti data yang dikemukan oleh Kunst. Proyek Penunjang Peningkatan Kebudayaan Jawa Barat yang dipimpin Enoch Atmadibrata menginventaris rumpun angklung di wilayah Sunda, Jawa Barat, terdiri 21 jenis, antara lain: angklung buhun Baduy-Banten, angklung gubrag di Cipining Bogor, angklung bungko di Bungko Cirebon, angklung badud di Cijulang Ciamis, angklung badéng di Sanding Garut, angklung buncis di Banjaran-Bandung, dan angklung sunda/Indonesia di Saung Angklung Udjo Padasuka Bandung (Mack, 2003:4). Sedangkan untuk wilayah yang cakupannya lebih besar, yakni Indonesia, angklung tersebar di beberapa pulau yakni pulau Jawa, Madura, Bali, Sumatera, dan Kalimantan (Pradoko, 2013:33). Apabila diinventaris dan dikalkulasikan satu persatu pada setiap daerah di Indonesia dipastikan varian seni angklung menjadi lebih kaya jenis dan ragam.

Penelurusan angklung yang diakui UNESCO, dikaji dengan menerapkan cara berpikir diakronik atau menganalisis secara berurutan (kronologis). Penelusuran 
dimulai saat Malaysia mendaftarkan hak paten atas angklung ke UNESCO, ${ }^{9}$ dengan dasar instrumen yang digunakan mengiringi kesenian kuda kepang di kota Johor Malaysia. Klaim tersebut dipertegas ulasan pada situs resmi, www.musicmall_asia.com dan www.malaysiana.pnm.my bahwa kesenian kuda kepang dan angklung merupakan warisan budaya Malaysia. ${ }^{10}$ Pengunjung situs mendapat penjelasan mengenai bahan dasar angklung, fungsi, dan cara memainkannya, disertai foto angklung dan suara angklung yang diperdengarkan dengan mengklik ikon speaker (Kalsum, viva.co.id).

Entitas angklung pada kesenian kuda kepang di Johor Malaysia menjadi dasar pengidentifikasian mengenai ikhwal jenis angklung yang menjadi objek rebutan kepemilikan antara Malaysia dengan Indonesia. Aspek yang diidentifikasi adalah sistem tangga nada angklung pada seni kuda kepang di Johor Malaysia ternyata pentatonik, saléndro (www.youtube.com/watch?v=PDkjo3Kju8o). Identifikasi tangga nada merupakan konklusi awal yang dijadikan 'kunci' untuk membuka 'pintu gerbang' penganalisisan selanjutnya, yakni identifikasi kategori jenis angklung. Saléndro sebagai tangga nada pada angklung Malaysia, ternyata adalah tangga nada tertua yang ditemukan di Indonesia: "Salendro is a pentatonic scale, the older of the two most common scales used in Indonesian music, the other being pélog." (https://en.wikipedia.org/wiki/Slendro). Keberadaan sistem tangga nada Saléndro yang melembaga dan mentradisi ini, identik melekat pada kesenian tradisional di Indonesia.

Lalu apakah kesenian kuda kepang adalah kesenian yang orsinilitas dari Malaysia? Sekedar informasi keberadaan Kuda Kepang di Malaysia dipaparkan Asia Calling melalui film dokumenter Atraksi Kuda Kepang di Malaysia, sebagai kesenian yang dibawa imigran Jawa pada awal abad 19. Kesenian kuda kepang terus dipelihara para imigran Jawa tersimpan dalam ruang dan waktu, mengkristal dan melembaga hingga tumbuh dan berkembang di Malaysia menurunkan beberapa generasi seniman. Hal itu mendasari Malaysia merasa memiliki kedekatan budaya, dan mengajukan hak paten atas angklung dan kuda kepang sebagai warisan budaya milik Mereka.

Reaksi masyarakat Indonesia atas pendaftaran angklung sebagai warisan budaya Malaysia menimbulkan kontroversi. Terhenyak dan tersadar atas kebangsaan (etnisitas) dan rasa kepemilikan kesenian yang ada di lingkungan budaya sendiri (baca: Indonesia). Masyarakat Musik Angklung resah karena angklung akan dipatenkan Malaysia. Apabila terealisasi, proyeksi pada masa datang adalah pengurusan izin, royalti, dan administrasi yang mesti dilayangkan kepada pemerintah Malaysia, ketika

${ }^{9}$ Negeri jiran Malaysia gencar melakukan propaganda pariwisata yang mengklaim beberapa kesenian Indonesia adalah milik Malaysia. Kesenian yang diklaim Malaysia antara lain seni Batik, reog ponorogo, kuda kepang (kuda lumping), tari Pendet, Tari Piring, lagu Rasa Saayange, Tari Tor Tor Batak, Gamelan Jawa, Keris, dan Jamu (http://www.jpnn.com/read/2012/06/18/131013/)

${ }^{10}$ Kini situs resmi Malaysia tersebut tidak dapat diakses karena telah ditutup oleh pengelolanya. 
seniman Indonesia memproduksi atau memainkan instrumen angklung. Padahal bagi bangsa Indonesia, angklung telah menjadi bagian kehidupan sosial budaya mereka jauh berabad-abad lampau lamanya.

Akhirnya pada tahun 2009 Indonesia mendaftarkan angklung ke UNESCO yang berkedudukan di Paris Perancis, Organisasi Pendidikan, Keilmuan, dan kebudayaan Perserikatan Bangsa-Bangsa (PBB). ${ }^{11}$ Hal ini merupakan pengulangan peristiwa yang terdahulu - antara Indonesia dengan Malaysia - di mana Indonesia memenangkan seluruh klaim Malaysia atas warisan budaya yang dimiliki Indonesia, yakni wayang kulit pada tahun 2003, keris pada tahun 2005, dan batik pada tahun 2009. Pada tahun 2009 Penulis terlibat sebagai peserta pada Sidang Verivikasi Angklung untuk dicatat sebagai Warisan Budaya tak Benda bertempat di Saung Angklung Udjo Bandung. Hasil sidang menjadi dasar untuk diajukan dan pertimbangan UNESCO. Berdasarkan bukti sejarah dan data-data yang dikirimkan kepada UNESCO, pada tanggal 16 November 2010 Angklung dikukuhkan sebagai Warisan Tak Benda dunia atau Intangible, Cultural Heritage of Humanity dari Indonesia.

Angklung yang menjadi dasar pengakuan UNESCO adalah seluruh angklung yang ada di Indonesia - baik angklung tradisional maupun modern - karena keduaduanya memperlihatkan konsistensi masyarakat pendukung angklung di Indonesia dalam memelihara seni warisan leluhur dan mengembangkannya hingga lahir kesenian angklung yang disebut angklung padaeng ${ }^{12}$. Angklung tradisional dengan sistem tangga nada pentatonik menginspirasi kemunculan angklung padaeng yang menggunakan sistem nada kromatik (well-tempered scale, yaitu tangga nada yang terdiri atas 12 nada peroktaf), keduanya seolah-olah seperti dua sisi 'mata uang' yang tidak dapat terpisahkan. Keterkaitannya seperti gambaran analogi yang dikutip dari naskah kuna Amanat Galunggung berikut ini:

\section{Hana nguni hana mangke tan hana nguni tan hana mangke aya ma beuheula aya tu ayeuna hanteu ma beuheula hanteu tu ayeuna hana tunggak hana watang tan hana tunggak tan hana watang hana ma tunggulna aya tu catangna.}

11 Sebelumnya saling klaim antara Malaysia dengan Indonesia pernah terjadi, memperebutkan hak paten atas batik, klaim dimenangkan Indonesia pada tahun 2009

12 Disebut Angklung Pakdaeng karena Daeng Soetigna yang pertama kali membuat dan mengembangkannya. Daeng Soetigna seorang guru HIS pada jaman kolonial Belanda di Kabupaten Kuningan Jawa Barat. Pada tahun 1938 berhasil membuat satu set angklung diatonik, yang kemudian digunakannya untuk mengajar anak-anak kepanduan (Pramuka) (Pradoko, 2013:34) 
Terjemahan

Ada dahulu ada sekarang

bila tidak ada dahulu tidak akan ada sekarang

karena ada masa silam maka ada masa kini

bila tidak ada masa silam tidak akan ada masa kini

ada tonggak tentu ada batang

bila tidak ada tonggak tidak akan ada batang

bila ada tunggulnya tentu ada catangnya.

Naskah di atas dapat diinterpretasi sebagai fenomena angklung yang tidak bisa lepas dari ruang dan waktu. Ruang adalah wilayah geografis masyarakat yang menjadi lokus tempat angklung itu hidup dan berkembang. Sedangkan waktu dapat diartikan sebagai skala interval antara dua keadaan, yakni dahulu dan sekarang (Pusat Bahasa, 2008:1614). Angklung telah hidup pada lokus masyarakat Sunda melewati perjalanan waktu yang sangat panjang. Oleh karena itu ketika berbicara mengenai angklung pa daeng tentunya tidak bisa lepas dari entitas angklung tradisional pada masa lampau. Hal itu dapat dipahami laiknya konsep relasi antara 'akar' dan 'tanaman', di mana akar adalah perintis atau yang mengawali perjalanan tanaman tumbuh besar, berdaun dan berbuah. Begitu pula dengan angklung tradisional yang menjadi entitas dari kemunculan angklung modern seiring proses waktu, di mana angklung tradisional adalah akar dan angklung modern yang menjadi daun atau buah.

\section{Angklung Tradisional, Bambu, Dewi Padi, dan Teknologi}

Angklung tradisional masyarakat Sunda merepresentasikan tradisi masyarakat Sunda lama; penjaga keseimbangan kosmologi ‘dunia atas dan bawah' atau antara

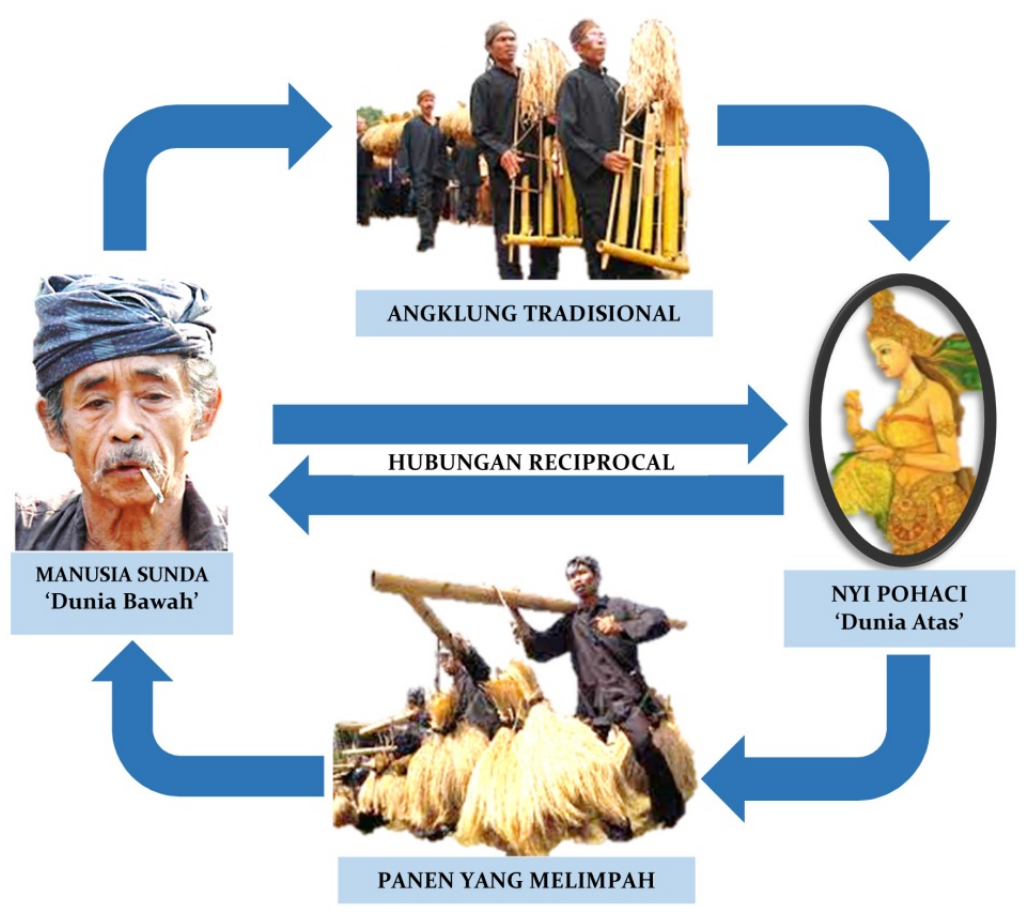

Jurnal Awi Laras manusia dengan penguasa di Kahiyangan; dipertunjukkan saat kegiatan menanam/memananen padi; dan bentuk sajian ritual musikal untuk Dewi Padi atau dalam mitologi Sunda disebut Nyi Pohaci Sanghyang Sri. Musikalisasi tabuhan angklung adalah pengejawantahan keinginan Nyi Pohaci untuk memberi 'spirit' kepada tanaman padi yang ada di 'dunia bawah'. Seolah-olah seperti kontrak yang disepakati antara Nyi Pohaci dengan manusia Sunda (Baier, 1985:9), menunjukan hubungan 
reciprocal (timbal-balik), di mana esensi garap tetabuhan angklung ditujukan agar tanaman padi tumbuh, berkembang, dan menghasilkan panen yang melimpah, sepanjang manusia Sunda konsisten untuk 'menghibur' Dewi Padi, dan merawatnya selama tahapan siklus pertanian berlangsung. Hubungan tersebut digambarkan skema di samping:

Selama musim tanam, komunitas masyarakat adat Sunda di Banten Selatan atau Kanekes memasang calintu dan kolecer, yakni alat dari bambu, menghasilkan bunyi berdengung apabila tertiup angin. Bunyi-bunyian tersebut difungsikan untuk menemani dan menghibur Dewi Padi di ladang, agar 'hatinya' senang dan padi pun tumbuh sumbur (Mack, 2003:26).
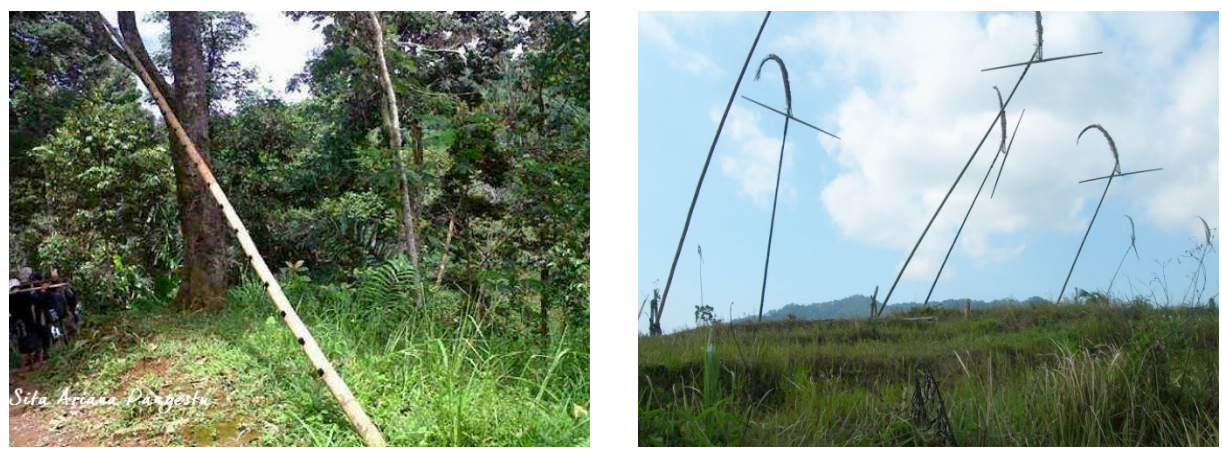

Calintu dan kolecér di landang, alat dari bambu yang menghasilkan bunyi frekeunsi low decible, menghibur dewi padi (diunduh dari google image)

Bentuk kearifan lokal (local genius) di atas, yang kesahihannya mungkin bagi 'manusia yang sekarang menyebut dirinya 'manusia modern' adalah nonsense, tidak masuk akal, tahayul, dan di luar logika, apalagi dikaitkan dengan kekuatan transendental dari tokoh mitologi bernama Nyi Sri atau bunyi-bunyian dari angklung, calintu, dan kolécér yang membuat tanaman padi tumbuh subur. Berabad-abad kemudian kearifan lokal yang dipercaya orang Sunda ini dibuktikan kebenarannya, melalui percobaan ilmiah dan aplikasi perangkat ilmu pengetahuan para ilmuan dari Amerika Serikat, dengan sintesa bahwa entitas musik mempengaruhi pertumbuhan tanaman dan dapat diaplikasikan sebagai agribisnis yang menjanjikan. Pembuktian tersebut dikutip dari buku Agribisnis Kreatif: Pilar Wirausaha Masa Depan Kekuatan Dunia Baru Menuju Kemakmuran Hijau (2012) berikut ini:

Aplikasi seni musik dalam bidang pertanian laik dijadikan model agribisnis kreatif. Betapa tidak seni musik (musik klasik) yang selama ini hanya dinikmati dan dimanfaatkan untuk kehidupan manusia, kini oleh para pelaku kratif telah pula dimanfaatkan dalam dunia pertanian. Beberapa tanaman seperti tanaman hias dan buah-buahan, yang sejak tumbuh, berkembang, berbunga, hingga berbuah diiringi dengan musik klasik terbukti memiliki karakter, kualitas, bentuk, dan ukuran yang berbeda dari biasanya. Penelitian Sherry Shinholster dan David Harris menyimpulkan tanaman menikmati musik dan memiliki masa 
hidup yang lebih lama bila terkena gelombang musik yang sesuai. Tanaman yang sebagian besar tubuhnya terdiri dari air mampu menangkap atau mendengar suara musik, memiliki gen yang dapat 'mendengar' (Setiawan, 2012:241-242).

Tradisi pertanian yang melibatkan bunyi-bunyian angklung, calintu, dan kolécér, efektif mengusir hama tanaman; menghalau burung pemakan padi dan mensterilkan fertilitas hama tikus saat reproduksi karena terusik riuh tetabuhan. Frekuensi getaran bunyi low decibel dari calintu dan kolécér menimbulkan efek menyakitkan yang dirasakan hama jenis serangga, sehingga bermigrasi menjauhi area ladang dan sawah (www.merdeka.com). Kearifan lokal masyarakat Sunda berkomunikasi dengan alam, memanfaatkan alat musik dari bambu untuk mengusir hama tanaman, mungkin dipandang kuno atau nosense, tetapi jika memang terbukti kebenarannya, maka dipastikan aplikasi kearifan lokal tersebut tidak menggangu keseimbangan ekosistem karena rantai makanan terputus seperti penggunaan pestisida dan obat kimia pertanian yang mencemari lingkungan.

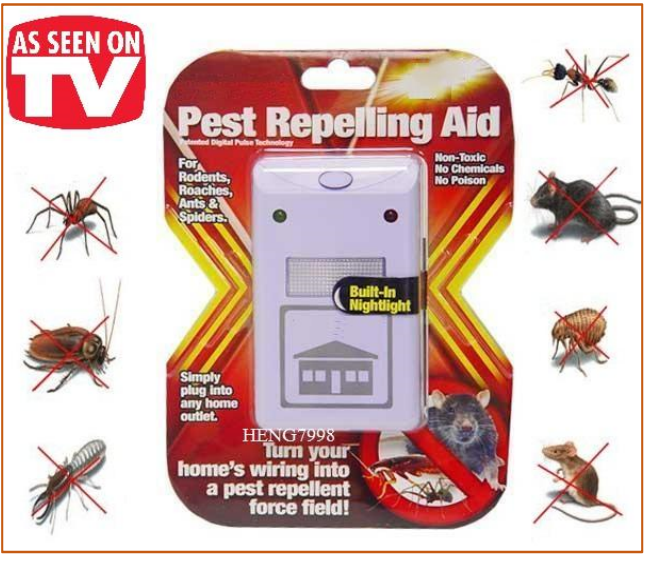

Pest Repelling Aid alat pengusir hama tikus dan serangga yang menghasilkan frekuensi bunyi yang serupa dengan bunyi angkung (www.usirtikus.com)

Kebenaran atas getaran dan frekuensi bunyi berpengaruh terhadap tikus dan serangga menjadi penemuan ilmuan asing dekade ini. Padahal aplikasi kearifan lokal dari bunyi angklung, calintu, dan kolécér mengusir hama yang diterapkan leluhur bangsa Indonesia selama berabad-abad lampau, jauh sebelum peneliti asing memformulasikan dan meneorikan juga membuktikan pengaruh frekuensi bunyi terhadap serangga dan tikus. Pada akhirnya, Sains Barat jualah yang mendahului dengan memvalidasi keabsahan dari kearifan lokal leluhur Nusantara. Sains Barat menemukan alat elektronik pengusir tikus dan serangga, yakni alat yang menghasilkan bunyi pada frekuensi getaran tertentu, berpengaruh terhadap tikus dan serangga yang terusik, sehingga menjauhi area yang dipasang alat tersebut. Masyarakat Indonesia menjadi konsumen alat tersebut (termasuk penulis), yang membeli pest repelling aid setelah menyaksikan acara home shopping di televisi.

\section{Angklung Tradisional Masyarakat Kanekes}

Angklung tradisional intens dipertunjukkan dalam tradisi pertanian masyarakat adat Sunda, salah satunya masyarakat Kanekes. ${ }^{13}$ 'Kabar burung' menceritakan

13 Masyarakat Kanekes atau Baduy merupakan masyarakat adat Sunda yang secara administrasi tergabung dengan Propinsi Banten sebagai pemerintahan baru yang memisahkan diri dengan Propinsi Jawa Barat pada tahun 2000. Keberadaan masyarakat Kanekes diakui sebagai model gambaran kehidupan sosial budaya 
masyarakat Kanekes merupakan keturunan aristrokrat kerajaan Pajajaran yang meloloskan diri dari penaklukan kerajaan Islam pada tahun 1579 (Spiller, 2008:111). Mereka mengisolasi diri ke wilayah pegunungan Kendeng di Banten Selatan, kukuh menjaga nilai-nilai dan kemurnian budaya yang diwariskan leluhurnya. Bentuk pengisolasian dan kekukuhan tersebut, mendudukan masyarakat Kanekes sebagai representasi penjaga tanah Sunda beserta ketradisiannya (Ekadjati, 1984:24-25, \& Spiller, 2008:111). 75 \% keaslian tatanan kehidupannya masih relatif asli dan representasi berdasarkan tatanan kehidupan masyarakat Sunda lama (Sukanda, 1996:4).

Aturan untuk menjalankan tatanan kehidupan sosial budaya masyarakat Sunda lama yang dianut masyarakat Kanekes menciptakan konsekwensi bagi anggota yang melanggar. Konsekwensi yang diterima yakni pendikotomian wilayah tempat bermukim, yakni: (1) yang tinggal di wilayah Tangtu disebut Baduy Dalam; (2) yang tinggal di wilayah Panamping disebut Baduy Tengah; (3) dan yang tinggal di wilayah Dangka disebut baduy luar (Mack, 2003:25). Masyarakat Tangtu disebut urang rawayan (keturunan Pajajaran) karena menganut sistem kemandalaan penuh dan belum melanggar aturan adat dengan menolak modernisasi dari 'dunia luar' (Mack, 2003:25). Sedangkan masyarakat Kanekes yang ditempatkan di wilayah panamping dan Dangka, adalah tempat pembuangan atau hukuman bagi masyarakat Tangtu yang melanggar adat, status kemandalaannya tidak penuh, resistensinya sedikit longgar sehingga ada kemungkinan bersentuhan dengan 'dunia luar' dan modernisasi (Mack, 2003:26).

Mata pencaharian masyarakat Kanekes adalah berladang, menanam padi huma (padi kering, bukan padi basah atau sawah yang mensyaratkan selalu dialiri air) dengan sistem berpindah tempat setiap tahunnya. Lahan yang pernah digarap, dapat dipergunakan kembali setelah masa tenggang 3 - 5 tahun (disebut masa bera). Mereka dilarang menjual padi, karena harus disimpan di leuit dan dipergunakan untuk kebutuhan sehari-hari; kegiatan berladang harus sesuai dengan sistem kalender buhun atau penanggalan berdasarkan rasi bintang (Mack, 2003:8 \& Permana, 2006:41); angklung tidak sembarang dimainkan tempat dan waktu, tetapi pada upacara menanam padi dan menyimpan padi ke leuit; padi tidak boleh diperjualbelikan (Mack, 2003:26 \& Permana, 2006:44). Aturan-aturan semacam itu mengkristal dan melembaga, secara implisit mengindikasikan adanya pedoman sebagai regulator yang senantiasa dipatuhi. Konsepsi tersebut tidak dituliskan, tetapi mendarah daging dan tertanam dalam tingkah laku perbuatan, tanpa dikomunikasikan atau diintruksikan dan diperintahkan pun, masyarakat Kanekes konsisten menjalankan konvensi yang diwariskan leluhurnya hingga sekarang.

masyarakat Sunda pada masa lampau. Mereka kukuh mempertahankan tata cara atau tradisi yang diwariskan leluhurnya, dengan mengisolasi diri dari pengaruh budaya di luar komunitas mereka. 
Angklung menjadi instrumen yang selalu ada dalam upacara siklus tanam dan panen padi di ladang pada masyarakat Kanekes (Ekadjati, 1984:28). Pada saat menanam padi, kaum laki-laki memainkan alat musik angklung, menyajikan repertoar khusus yang ditujukan kepada Nyi Pohaci Sanghyang Sri atau Dewi Padi. Iringan musik angklung merupakan ilustrasi dari penganalogian majas personifikasi, di mana masyarakat Kanekes sangat meyakini sebagai dogma yang tidak terbantahkan. Musikalitas tetabuhan angklung dipercaya medium 'membangunkan' Dewi Padi dari 'tidurnya', sekaligus mengantarkan menuju 'pelaminan' untuk melangsungkan perkawinan dengan Bumi (Spiller, 2008:112). Padi yang kawin dengan tanah (bumi) adalah gambaran personifikasi yang disematkan masyarakat Kanekes pada acara ngareremokeun Pohaci, di mana angklung sebagai pengiringi utamanya.

"The Baduy, or urang Kanekes as they prefer to call themselves, observe ritual and agricultural laws that restrict the performance of angklung to five month planting and culvation season. Among the Baduy, Nyi Pohaci is invoked during the planting season, in contrast to the ritual practicies in other areas of West Java (where Nyi Pohaci associated with the harvesting of rice). It is the angklung ensemble that is directly responsible for this invocation. As one Badui (Kanekes) musician told me. "for us, this is not an art form, this is a religion." (Baier, 1985:10-11)

Prosesi dimulai nurunkeun binih (menurunkan benih) dan nyoo binih (memilah benih) yang dilakukan kaum wanita. Nurunkeun binih merupakan personifikasi dari peristiwa Dewi Padi yang dibangunkan dari tidurnya, dilaksanakan secara khidmat dalam suasana hening oleh istri girang serat (juru tulis) dengan mantra: "tabe, Nyi Pohaci Sang Hiyang Asri, hayu urang ngalih ka weweg sampeg, ka mandala pageuh, mangka tetep mangka langgeng, balik ka imah beurang kénéh” (Permana, 2006:101). Kemudian padi diturunkan, disimpan di tanah lapang, diinjak-injak oleh kaum wanita menggunakan telapak kaki, agar gabah terlepas dari batang ikatan menjadi butiran (Mack, 2003:26). Prosesi dilanjutkan oleh kaum wanita untuk nyoo binih, yakni memilih gabah yang hampa untuk dibuang, dan yang berisi disimpan ke dalam bakul (Permana, 2006:102).

Pada malam hari, salah satu bakul dibawa ke Alun-Alun sebagai representasi simbolis yang mewakili bakul berisi benih lainnya, di sana barisan kokolot, pemain angklung, dan warga kampung telah menunggu (Mack, 2003:26). Kokolot membaca mantra: "Anten pihaturan ka baris kokolot, Nyi Pohaci Sang Hiyang Asri ndeuk direremokeun ku kami ka bumi, isukan ndeuk dikawinkeunana, mangka langgeng mangka tetep huripna, jayana Nyi Pohaci Sang Hiyang Asri” (Permana, 2006:102). Serentak yang hadir menjawab: "Nyakseni mangka lulus, mangka hurip, mangka tetep, mangka langgeng huripna, Nyi Pohaci Sang Hiyang Asri repok jeung bumi ti paratiwi" (Permana, 2006:102). Bakul berisi benih ditimang sambil diayun-ayun oleh kokolot seirama dengan iringan musik angklung pada lagu Pangreremo (perjodohan). Posisi 
bakul yang berisi benih menjadi titik pusat lingkaran, di mana pemain angklung mengitarinya (Mack, 2003:26). Pemain angklung memainkan komposisi musik, mengitari bakul padi yang menjadi titik pusat. Musik yang dimainkan serta gerak pemain angklung dan penari memberikan suasana pengasuhan, perdamaian, dan rasa nyaman. Laki-laki yang tidak memainkan angklung, ikut mengintari sambil menari, dan menyanyi mengikuti irama musik angklung, memegang selendang panjang berwarna biru, mengayun-ayunkannya, dengan gerakan disebut ayun-ayunan, seperti gerakan mengipasi bayi (Baier, 1985:10).

Angklung yang digunakan pada masyarakat kanekes terdiri atas sembilan buah angklung dari berbagai ukuran yang berbeda nada dengan sistem tangga nada pentatonik. Ada angklung yang bernada sama, tetapi dipastikan berbeda frekuensi. Tujuh buah angklung dimainkan pemain tunggal, kecuali dua angklung yang bernada tinggi dimainkan oleh seorang pemain. (Spiller, 2008:112). Pada masyarakat kanekes di wilayah Dangka dan Panamping permainan angklung pada upacara ngareremokeun Pohaci dilengkapi tiga buah alat musik membranophone, yakni dogdog lojor, dan ada tarian khusus yang menyertainya disebut Duum Peuteuy dan Pulung Puncang (Mack, 2003:27)

Setelah prosesi selesai, bakul disimpan pada tempat yang sama dengan bakul yang lain. Selain sebagai ritual menghibur Dewi Padi, malam itu merupakan rangkaian acara penyampaian komitmen yang disepakati bersama, bahwa besok dilangsungkan perkawinan antara Dewi Padi dengan bumi (ngareremokeun pohaci). Komitmen tersebut menjadi ancang-ancang bagi kaum laki-laki dewasa, untuk membuat lubang (ngaseuk) yang dikerjakan tepat pada saat rasi bintang kidang berada di puncak titik zenit $^{14}$ ketika waktu subuh (Permana, 2006:101).

Keesokan hari, lubang-lubang di tanah untuk benih padi telah dibuat. Bakulbakul berisi benih diarak menuju huma serang (di wilayah tangtu) dan huma tuladan (di wilayah panamping), diiringi tetabuhan angklung yang membawakan lagu Pileuleuyan diikuti seluruh warga (Mack, 2003:27). Setiba di lahan huma, percakapan warga dan tetabuhan angklung berhenti, benih padi diletakan di pupuhunan, lahan seluas satu meter persegi, menjadi pusat sakral untuk seluruh perladangan. Prosesi ritual pembacaan mantra dan pembakaran kemenyan dilakukan, diiringi tetabuhan angklung yang diperdengarkan seiring asap kemenyan yang membungbung ke angkasa (Permana, 2006:103). Angklung menjadi musik ritual pada upacara tersebut yang lama diperdengarkan. Seolah-olah menjadi musik pemberkatan dari prosesi perkawinan antara Dewi Padi dengan bumi. Lagu-lagu yang disajikan, antara lain: Lutung Kasarung, Lalaela, Lili-Liang, Jari Dangdan, Yandi Bibi, Cat Arileu, Ayun Ambing, Nganteh, Gantung Manggu, Pongpok, Badan Kula, Ngasuh, Bibi Lenjang, Hiah-Hiah

${ }^{14}$ Zenit adalah posisi tertinggi di bola langit khayal yang tegak lurus di atas kepala pengamat di bumi 
Panjang, Keupat Reundeung, Oray-Orayan, dan Pileuleuyan (Mack, 2003:27). Saat itu juga dilangsungkan prosesi muhunan yang dilakukan kaum wanita dewasa, yakni kegiatan memasukan benih padi (Dewi Padi) ke dalam lubang tanah (Bumi) (Permana, 2006:101).

Beberapa minggu setelah prosesi menanam padi, tetabuhan Angklung kembali diperdengarkan di ladang sebagai kelanjutan dari prosesi ritual, yakni menghibur Dewi Padi yang telah melangsungkan perkawinan dengan bumi, dengan harapan tumbuh subur melahirkan biji padi yang melimpah dan terbebas dari pengganggu (hama) yang dipercayai dalam mitologi mereka sebagai penjelmaan (inkarnasi) tokoh Budugbasu dan Kalabuat (Spiller, 2008:112). Penyajian angklung juga dilaksanakan setelah padi selesai dipanen, yakni pada acara ngunjal, yakni mengangkut padi ke leuit (Mack, 2003:27).

\section{Angklung Padaeng atau Angklung Indonesia}

Entitas angklung tradisional menginspirasi kemunculan angklung yang menggunakan sistem nada kromatik (well-tempered scale, yaitu tangga nada terdiri atas 12 nada peroktaf). Angklung tersebut diciptakan Daeng Soetigna, diberi nama Angklung Indonesia atau Angklung Modern, karena lagu-lagu yang diketengahkan adalah lagu Indonesia atau lagu yang bersifat kekinian (modern), bukan lagu tradisi seperti yang dipertunjukkan angklung tradisional. Istilah lain untuk angklung Indonesia adalah Angklung Padaeng. Penamaan tersebut diberikan murid-murid Soetigna, yang meneruskan tongkat estafet menyebarkan angklung karya Soetigna dan yang mengikuti perjuangan gurunya itu membawa Angklung ke tempat yang lebih terhormat (Sjamsuddin, 1986:30). ${ }^{15}$ Penyebutan 'Padaeng' mencitrakan aura penghormatan, karena nama itu merupakan sebutan murid-murid kepada sosok guru yang mengenalkan dan mengajari mereka Angklung. 'Pa' dalam bahasa Sunda adalah penyebutan untuk laki-laki dewasa atau berusia jauh lebih tua, diabsorpsi dari istilah 'Bapa'; sedangkan 'Daeng' adalah frist name dari guru angklung mereka, yakni 'Daeng Sutigna', jika dilafalkan 'Pa Daeng,' jika disatukan dengan istilah angklung, menjadi 'Angklung Padaeng'.

Peristiwa yang menginspirasi Soetigna untuk menciptakan angklung dimulai saat melihat dua orang pengemis yang memainkan angklung buncis di depan rumahnya (Sjamsuddin, 1986:30 \& Minarwati, 2012:288). Peristiwa tersebut menimbulkan kesan yang ditangkap dan ditanggapi Soetigna, sebagai rangsangan untuk memulai proses imajinasi, ide, tujuan penciptaan, dan kreativitas mewujudkan kekaryaan untuk mengangkat angklung ke tempat yang lebih terhormat, jangan

${ }^{15}$ Nama Daeng mempunyai riwayat tersendiri. Ayahnya memiliki sahabat dari Makasar yang bergelar Daeng. Daeng dari makasar ini sangat pandai. Ketika itu ibunya sedang mengandung dan ayahnya berkata bahwa, "kalau kelak anak yang dilahirkan laki-laki akan deberi nama Daeng, agar pandai seperti sahabatnya itu." Ketika itu anak yang lahir adalah laki-laki maka bayi itu diberi nama Daeng Sutigna (Sjamsuddin, 1986:3). 
seperti pengamen yang merendahkan kesenian angklung dengan cara meminta-minta. Kesadaran Soetigna diulas Mack berikut ini:

Daeng Soetigna berusaha merintis pengembangan pertunjukan angklung, karena dia melihat pertunjukan angklung hanya dijadikan sarana mencari nafkah dengan cara ngamen. Bagi Daeng Soetigna, kegiatan ngamen itu sangat memprihatinkan dan memalukan, sehingga dikembangkanlah angklung dengan sistem tangga nada diatonis agar dapat memberi perubahan dalam tingkat sosialnya (Mack, 2003:75).

Kesadaran untuk memperjuangkan angklung ke tempat yang terhormat bagi Soetigna disebabkan ikatan batin yang bersangkutan yang sejak kecil sangat senang memainkan angklung (Minarwati, 2012:288). Selain itu ada kebanggaan mengenai spiriit atau kekuatan angklung dari aspek historis yang menjadi kebanggaan Soetigna, dituturkan kepada Enoch Atmadibrata, ditulis dalam bulletin Kawit (1992) sebagai berikut:

Angklung telah menjadi kelengkapan dalam upacara ritual, sebagaimana suku Kanekes dalam upacara tanam padi. Pada abad 17 penyerangan Sultan Agung ke Banten diiringi musik perang dengan angklung, para pemainnya sebagian besar orang Bali. Suara angklung memberi kesan sakral dan pembangkit semangat yang berkobar-kobar, sempat mengkhawatirkan prajurit Belanda. Tidak heran musik angklung sempat dilarang oleh Belanda, yang diperbolehkan hanya bagi pengemis saja. Atas kenyataan itu, maka Daeng Soetigna almarhum berusaha membela kehormatan angklung, dengan cara merubah angklung yang pentatonis (salendro) ke dalam tangga nada diatonis. Beliau berguru membuat angklung kepada pak Jaya (kuningan), pengrajin angklung yang memasok angklung kepada para pengemis (Atmadibrata, 1992:83) ${ }^{16}$

Pelarangan pertunjukan angklung kecuali dipertunjukkan oleh pengemis, menjadi tantangan bagi Soetigna, untuk mengembalikan kejayaannya angklung, tidak berpretensi sebagai kesenian yang mengancaman stabilitas keamanan pemerintah Hindia Belanda. Berdasarkan pengidentifikasian masalah dan pencarian jawaban atas permasalahan, pada tahun 1930 Soetigna mulai menjalankan formulasi jawaban atas permasalahan tersebut, dimulai dengan belajar membuat angklung kepada Djaja, seorang pengrajin angklung di Kuningan (Atmadibrata, 1992:83, \& Minarwati, 2012:288). Harapannya ia dapat membuat sendiri instrumen tersebut. Pada tahun 1938, Soetigna mampu membuat angklung yang disesuaikan dengan imajinasi, ide, dan tujuan awal penciptaan yang telah dirancang agar angklung kembali pada martabat kehormatannya.

${ }^{16}$ Angklung bagi pemerintah Hindia Belanda diwaspadai karena mampu menggalang kekuatan massa yang banyak, berpretensi disalahgunakan menggalang pemberontakan. 
Imajinasi yang berisi konsep dan gagasan garap yang diimplemtasikan Soetigna, adalah membuat angklung dengan sistem tangga nada diatonis (tangga nada internasional). Secara musikalitas tentu berbeda dengan angklung tradisional pada masyarakat Sunda, dan hal itu menjadi poin penting bagi pemerintah Hindia Belanda untuk tidak mencekalnya, seperti dialami angklung tradisional. Angklung diatonis dapat menyajikan lagu-lagu populer, termasuk lagu bangsa asing sekalipun.

Nada-nada pada angklung ciptaan Soetigna disesuaikan dengan skala nada diatonik, yakni do, re, mi, fa, so, la, si, do, bukan skala pentanonik da, mi, na, ti, la (Pradoko, 2013:34). Angklung yang dibuat terdiri atas dua kelompok, yakni angklung melodi dan angklung kompanyemen. Jelajah angklung melodi mulai dari C oktaf besar hingga C'”. sedangkan Angklung kompanyemen berperan mengiringi angklung melodi, terdiri atas tiga tabung bambu yang menerapkan nada akor (Pradoko, 2013:35). Selain itu, Soetigna merintis penggunaan angklung yang diciptakannya bukan untuk menggalang massa seperti penggunaan angklung tradisi pada peristiwa menanam padi atau panen padi, melainkan diterapkan sebagai alat pendidikan, yakni siswa sekolah dan kepanduan di Kuningan.

Usaha Soetigna mulai menampakan hasil, bertepatan dengan usaha penyelesaian konflik antara Belanda dengan Indonesia (konflik terjadi karena Jepang menyerah tanpa syarat, Belanda berkeinginan menguasai kembali Indonesia yang telah memproklamasikan kemerdekakannya). Pada tanggal 12 November 1946, siswa sekolah dan kepanduan asuhan Soetigna diundang tampil memainkan angklung menghibur peserta perundingan Linggajati yang dilaksanakan di Kuningan (tempat Soetigna bermukim pada saat itu). Angklung diatonis yang dipimpin Soetigna mampu memukau tamu-tamu asing pada perjanjian Linggarjati (Minarwati, 2012:289). Kesempatan itu berlanjut pada tahun 1955, di mana Soetigna mempertunjukkan konser angklung pada Konferensi Asia Afrika di Gedung Merdeka Bandung (Minarwati, 2012:289). Semenjak itu eksitensi angklung karya Soetigna menjadi langganan yang selalu tampil di ruang publik yang lebih luas, menyambut tamu negara, wisatawan, dan misi kesenian di dalam negeri maupun luar negeri.

Kreativitas Soetigna yang menelorkan angklung ciptaannya, sebagai jawaban atas tantangan dan fenomena sosial yang terjadi pada masa itu, tak lain merupakan refleksi yang bersangkutan terhadap lingkungan kultur yang menjadi sumber rangsangan kreatif untuk ditanggapi, diberi konsep gagasan, dan diikuti dengan usaha Soetigna belajar membuat angklung, yang kemudian diaktualisasikan dengan karya, yakni pertunjukan angklung yang relatif baru atau berbeda dengan konvensi pada masyarakat tradisional Sunda. Alur proses penciptaannya seperti bagan berikut: 


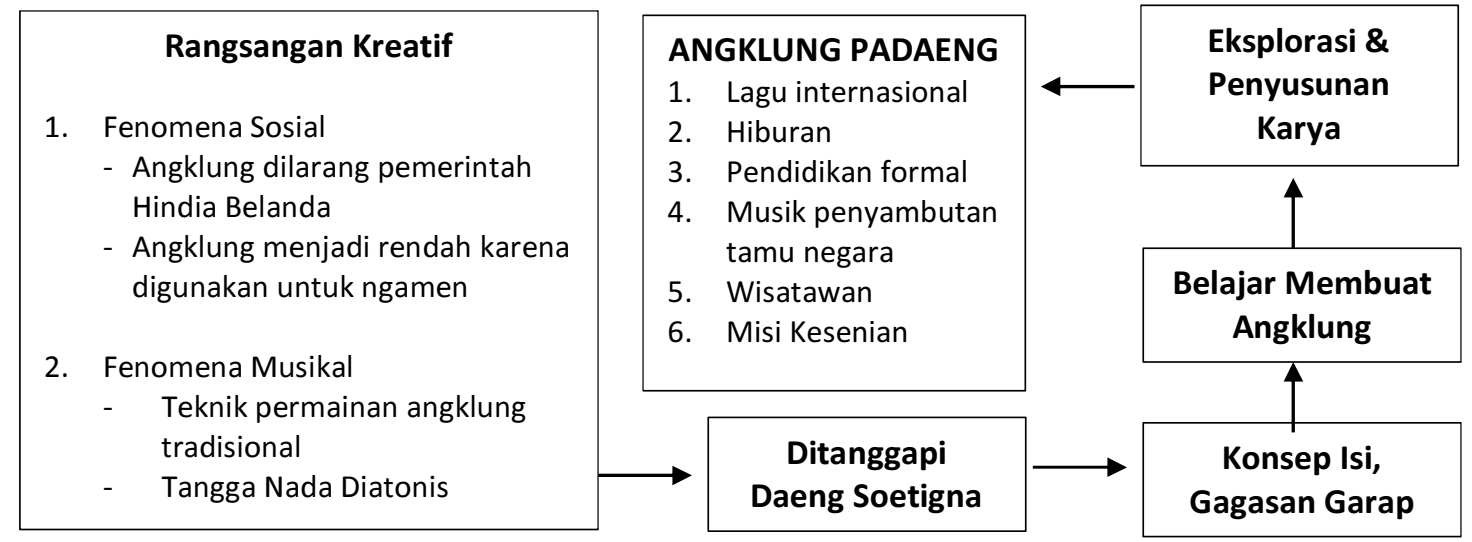

Peristiwa di atas mungkin di luar ekspektasi Soetigna pada awal menciptakan angklung diatonis, tetapi berdampak luar biasa. Semenjak angklung ciptaannya dipertunjukkan di hadapan tamu asing peserta konferensi Asia Afrika di Gedung Merdeka Bandung. Nama 'Daeng Soetigna' menjadi 'besar'. Konsekwensi logis yang harus diterima adalah kesibukan melayani tawaran mengisi acara kesenian bersifat pribadi maupun kenegaraan. Prestasi Soetigna itu dibalas dengan beasiswa untuk belajar di Colombo Plan Australia pada tahun 1955-1956 (Minarwati, 2012:288). Soetigna juga tampil pada acara World Fair di New York Amerika Serikat pada tahun 1964, dan memimpin misi kesenian Indonesia pada pertunjukan muhibah keliling di berbagai kota di Malaysia pada tahun 1967 (Minarwati, 2012:289).

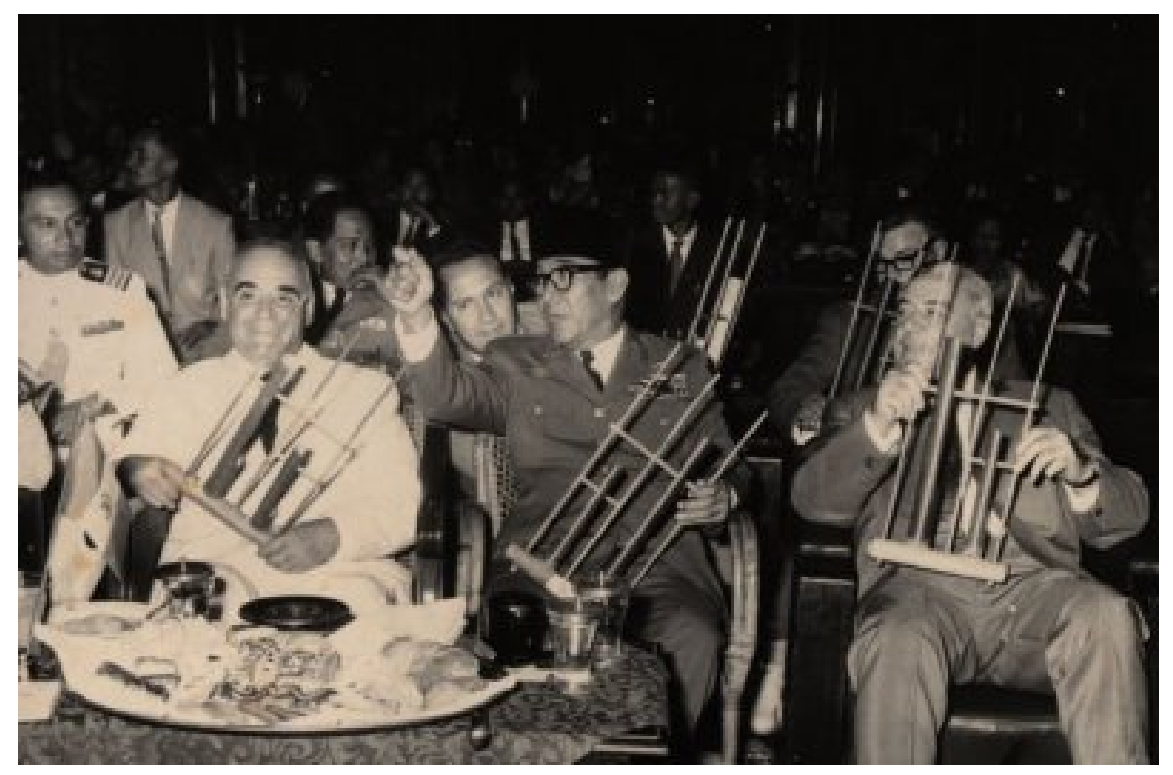

Persiden RI ke-1, Soekarno dan Persiden Rumania Gheorghe Gheorghiu beserta tamu asing memainkan angklung padaeng pada tahun 1962 di Bandung (Dok. KILTV, Unversiteit Leiden) 
Keberadaan angklung yang ditawarkan Soetigna secara resmi dijadikan alat pendidikan musik di sekolah dengan surat keputusan Menteri Pendidikan dan Kebudayaan No 082/1968 tertanggal 23 Agustus 1963 (Mack, 2003:76 \& Pradoko, 2013:35). Sejak tahun 1971 Pemerintah Indonesia menjadikan angklung sebagai sarana dalam program diplomasi budaya, sangat berdampak pada angklung diatonis yang diciptakan Soetigna dengan sistem nada kromatik menyebar ke seluruh pelosok negara:

Di Korea Selatan tercatat lebih dari 8000 sekolah memainkan angklung; di Argentina angklung telah menjadi mata pelajaran intrakulikuler yang menarik bagi siswa, demikian juga di Skotlandia. Sejak tahun 2002 Departemen Luar Negeri Republik Indonesia memberikan kesempatan bagi siswa siswi dari Mancanegara untuk belajar dan mengenali angklung di Indonesia (Pradoko, 2013:35)

\section{Penutup}

Angklung telah ditetapkan sebagai warisan budaya tak benda Indonesia. Pada mulanya digunakan untuk acara ritual pertanian, seperti yang dipertunjukkan masyarakat Kanekes dari jaman Sunda Kuna hingga sekarang. Seiring dengan perjalanan ruang dan waktu, berkembang menjadi seni yang berfungsi sebagi hiburan. Entitasnya mampu mencitrakan (memberi identitas) suatu suku bangsa, suatu komunitas masyarakat, dan lebih luasnya lagi suatu bangsa. Hal ini menjadi satu kebanggan karena entitas angklung yang menjadi identitas Indonesia diperjuangkan dengan susah payah.

\section{Sumber Kepustakaan}

Atmadibrata, Enoch.

1992 “Musik Bambu." Bulletin.Kebudayaan Jawa Barat Kawit no 45. Bandun: Yayasan Kebudayaan Bandung.

Baier, Randal.

1985 "The Angklung Ensemble of West Java: Continuity of an Agricultural Tradition.” Balungan Volume II No 1-2 Fall 85/Winter 86. California: A Publication of the American Gamelan Institute.

Kunst, Jaap.

1948 Music in Java. The Hague, Netherlands: Martinus Nijhoff.

Mack, Dieter [ed].

2003 Angklung di Jawa Barat: Sebuah Perbandingan. Bandung: Pusat Penelitian dan Pengembangan Pendidikan Seni Tradisional Universitas Pendidikan Indonesia (P4ST). 
Pradoko, A.M. Susilo.

2013 "Fenomena Kesenian Angklung Sebagai Bentuk Pertemuan Nilai-Nilai Budaya Timur Menuju Barat: Lokal Menuju Global.” Prosidingn $5^{\text {th }}$ International Conference on Indonesian Studies: Ethnicity and Globalization. Yogyakarta: Fakultas Ilmu Pengetahuan Budaya Universitas Indonesia.

Permana, Cecep Eka.

2006 Tata Ruang Masyarakat Baduy. Jakarta: Wedatama Widya Sastra.

Pusat Bahasa.

2008 Kamus Bahasa Indonesia. Jakarta: Departemen Pendidikan Nasional.

Rosidi, Ajip [ed].

2000 Ensiklopedi Sunda: Alam Manusia, dan Budaya Termasuk Budaya Cirebon dan Betawi. Jakarta: Pustaka Jaya.

Sjamsuddin, Helius., \& Hidayat Winitasasmita

1986 Daeng Sutigna: Bapak Angklung Indonesia, Jakarta: Departemen Pendidikan dan Kebudayaan Direktorat Sejarah dan Nilai Tradisional Proyek Inventarisasi dan Dokumentasi Sejarah Nasional.

Setiawan, Iwan.

2012 Agribisnis Kreatif: Pilar Wirausaha Masa Depan Kekuatan Dunia Baru Menuju Kemakmuran Hijau. Depok: Penebar Swadaya.

Suparli, Lili., \& Asep Nugraha

2009 Peristilahan Karawitan. Bandung: Sunan Ambu STSI Press

Spiller, Henry.

2008 Gamelan Music of Indonesia: second edition. New York: Routledge.

Yamin, Muhammad.

1956 Atlas Sedjarah. Jakarta: Djambatan.

\section{Rujukan Elektronik}

Awa.

2012 "Inilah Daftar Kebudayaan Indonesia Pernah Diklaim Malaysia." Melalui http://www.jpnn.com/read/2012/o6/18/131013 [Senin, 18/06/2012]

Encyclopædia Britannica, Inc

2015 “Angklung”. Melalui http://www.britannica.com/art/angklung [2015] 
Fikri, Ahmad.

2010 "Angklung Diakui Unesco Sebagai Warisan Budaya Dunia." Melalui http://nasional.tempo.co/read/news/2010/10/18/o79285489 [Senin,18/10/2010]

Kalsum, Umi.

2010 "Fakta Angklung Budaya Indonesia Diungkap: Tidak hanya Batik, Wayang, dan beberapa Lagu, Malaysia juga Mengklaim Angklung." Melalui http://nasional.news.viva.co.id/news/read/135822 [Kamis, 11/03/2010].

KILTV Unversiteit Leiden

1962 President van Roemenië Gheorghe Gheorghiu-Dej (linksvoor) en president Soekarno (midden) met angklung muziekinstrumenten in een zaal te Bandoeng [10/07/2006]

Rosadi, Dian.

2015 "Karinding Alat Musik Pengusir Hama Hingga Pemikat Wanita." Melaui http://www.merdeka.com/artis/karinding-alat-musik-pengusir-hama-hingga-pemikatwanita.html [Selasa, 27/10/2015]

Wikipedia

2015 "Slendro." Melalui https://en.wikipedia.org/wiki/Slendro [12/09/2015] 